\title{
ON THE GAMETOPHYTES AND EMBRYO OF TAXODIUM.
}

CONTRIBUTIONS FROM THE BOTANICAL LABORATORY OF THE JOHNS HOPKINS UNIVERSITY, NO. I.

W. C. COKER.

(WITH PLATES I-XI)

(Concluded from p. 27)

FORMATION OF VENTRAL CANAL NUCLEUS.

Murrill ('OO) has recently described in Tsuga a peculiar method of spindle-formation in the division of the central cell of the archegonium. He finds a kinoplasmic area in contact with the inner side of the nucleus just before its division. Fibers begin to grow from this area into the nucleus, pressing before them the nuclear wall. They gradually extend until they come to occupy the greater part of the nuclear cavity, and are then joined by similar fibers which have come in from the opposite pole to form the prophase of the spindle. These observations I cannot confirm in Taxodium. Figs. 76-9o show this division in detail. As already stated, fibers pass around the nucleus from the kinoplasmic areas or aster and merge insensibly into the nuclear wall. The nuclear wall is frequently considerably drawn in at a point opposite the kinoplasmic body (figs. 76,78 ), but no strong fibers can be seen extending from one to the other at this point. In fact, this collapse is generally more noticeable in the early stages of preparatory changes. Murrill ('OI) finds such fibers, which he concludes have caused the depression of the nuclear wall.

The arrangement between aster and nucleus at this time may be best compared to that between the car of a balloon and the bag above it, the ensheathing fibers of the nucleus terminating in the aster representing the ropes around the balloon connecting it with the car below. Fig. 76 shows the beginning of the changes in the nucleus which lead to the formation of the spindle. 
Synapsis has occurred, and the nuclear reticulum forms a dense tangle near the nucleolus. The latter can now be distinctly seen to be of compound structure, and from it threads can be traced into the network. Fine threads also connect the conspicuous central tangle with the nuclear walls. Such a synapsis stage is described by Murrill in the nucleus of the central cell of Tsuga. In fig. 72 the reticulum has begun to move back into its original position. The nucleolus is now distinctly fragmented into a number of granules of apparently equal size, which gradually become more and more separated into a broken ring or coiled thread (figs. $7^{8-80}$ ). These granules retain the deep red stain characteristic of the nucleolus in previous stages. The ring, or thread, is now broken up more and more into separate parts and distributed near the periphery of the nucleus (figs. $8 I-84)$ and the reticulum of the nucleus begins to arrange itself for the formation of the spindle (figs. 83-85). The fibrous connections between the reticulum and the nucleolar thread are to be noticed at all stages of its distribution.

The red-staining granules derived from the nucleolus have not lost their identity at any stage. They become gradually elongated and thin (figs. 85, 86), and thus approach more and more the characteristic structure of the chromosomes. The fibers of the reticulum draw together at different points of the nucleus and certain centrally placed ones become distinguishable as spindle fibers, while the mantle threads pass gradually into the unmodified reticulum of the nucleus. The granular nature of the spindle is evident even at so late a stage as fig. 86. The nuclear wall has meanwhile disappeared, but its position is indicated by the arrangement of the fibers until the anaphase stage of division ( $f \mathrm{~g}$. 87). The chromosomes, as they are drawn apart, are of the usual $\mathrm{V}$ or $\mathrm{U}$ shape $(f i g .87)$. The transformation of the nucleolus into the chromosomes may be followed without interruption through its whole course, not only by reactions in staining, but in serial development.

Chromatin nucleoli have frequently been described, but principally among the lower plants. Strasburger ('oo) in his recent work devotes considerable space to the discussion of the part 
played by the nucleolus in the formation of the spindle. He reviews the present knowledge of the subject, and while acknowledging the chromatin character of the nucleolus in a few cases, expresses himself as strongly inclined toward the view that in the higher plants at least it is of kinoplasmic or spindle-building material. Nucleoli of chromatin character have been described in Corallina by Davis ('98), in Spirogyra by Mitzkewitsch ('85), in Bignonia by Duggar ('99), and in a number of other plants. That the nucleolus of the central cell in Taxodium is directly transformed into chromosomes seems to be evident from the figures given, and I think we may be equally sure of the intranuclear origin of the spindle. The kinoplasmic mass at the tip of the spindle seems to serve merely as a point of attachment for the spindle fibers, its numerous radiations making a firm foundation for the orientation of the spindle, as suggested by Murrill ('OI).

The nucleus of the central cell, just before its division, is generally situated not far from the tip of the archegonium, but it is often found as much as a third of the way down. In such cases the central vacuole, which is now much smaller, lies nearer the base of the archegonium. The wall of the nucleus is at the very surface of the cell (figs. 66,78 ), and it is often impossible to distinguish any protoplasm between nucleus and surface. In figs. 88 and 89 there is to be noticed in the center of the spindle a broad zone which is composed of numerous granules. In Flemming's triple this zone stains a deeper violet than the other parts of the spindle, and occupies the position at which we might expect to find a cell plate. No cell plate is formed, however, and the whole spindle fades away into the cytoplasm of the cell. At the surface end of the spindle shown in $f i g .87$ a small aster has appeared. The daughter nuclei are formed in the centers of these asters ( $\mathrm{fg}$. 88), and as they increase in size the kinoplasm is collected more and more on the sides toward the spindle (figs. 89, 90). In this way the egg and ventral canal nuclei are both furnished with a tuft of kinoplasm on their inner faces. Other tufts may be located at different positions around the egg nucleus ( $f g$. go), but in 
later stages the egg nucleus is nearly always furnished with but a single tuft on the side toward the base of the archegonium. The spindle may be situated in every position in reference to the axis of the archegonium, parallel ( $f g .87$ ), perpendicular (fig. 88), or inclined (figs. 86, 89), but the inner pole is always located in the center of the aster. The spindle may extend either up or down from the inner pole, and the ventral canal nucleus may thus be placed either above or below the egg nucleus $(f g .9 I)$. The archegonium to the right in fig. 92 shows a ventral canal nucleus situated nearer the base than the tip, and in the archegonium to the left the ventral canal nucleus occupies a nearly central position, the egg nucleus lying even lower. It is only rarely that the ventral canal nucleus is situated at the very tip of the egg. Such a position is shown in figs. 87 and 90 .

This formation of the ventral canal nucleus in any region other than near the tip of the archegonium has not been described in any other gymnosperm so far as I am aware. This peculiarity in Taxodium seems to be an acquired character for the protection of the ventral canal nucleus during fertilization, for, as we are to see later, it is to play a part in the subsequent history of the egg. In most gymnosperms the ventral canal nucleus is furnished with a certain amount of protoplasm of its own which is distinctly separate from that of the egg. Arnoldi ('oo) lays stress on what he calls the absence of a ventral canal cell in Cephalotaxus. He considers the ventral canal cell lacking because no wall is formed between the ventral canal nucleus and the egg. In this case, however, a certain amount of protoplasm becomes disorganized around the ventral canal nucleus, and swelling up is said to burst open the neck of the archegonium. If this is the case, the disorganizing protoplasm may be considered as belonging to the ventral canal nucleus, and a ventral canal cell could not strictly be said to be absent.

In Taxodium, however, not even a cell plate is formed, and the ventral canal nucleus lies perfectly free in the cytoplasm of the egg without a distinct protoplasmic area of its own. A ventral canal cell in the strict sense is therefore lacking here. 
From Strasburger's ('79) account it seems probable that this is equally true in the Cupresseae. Ikeno ('OI) has well remarked that the important point is the division of the nucleus and not the separation of a small amount of protoplasm from the egg. Arnold ('99) denies the occurrence of even a ventral canal nucleus in Sequoia.

The ventral canal nucleus remains closely applied to the surface of the egg and is somewhat flattened or compressed. It does not go through the peculiar changes which occur in the egg nucleus before fertilization, but having reached the condition shown in fig. 90 does not develop much further until after the fertilization of the egg. It is furnished with a chromatin reticulum and an evident nucleolus. The ventral canal nucleus has usually been described as undergoing disorganization soon after its formation, sometimes reaching a resting condition, but generally never developing further than the first stages of this condition (Blackman, '98; Ikeno, '98; Murrill, 'o I, among others). Chamberlain ('98) figures a well-developed nucleus in the young fertilized archegonium of Pinus Laricio, which closely resembled the egg nucleus and which is, as he suggests, in all probability the ventral canal nucleus. Very recently Ikeno ('OI) has described a large nucleus in the tip of the egg of Ginkgo and called it a ventral canal nucleus. He also calls attention to the possibility that a persistent ventral canal nucleus may have been mistaken for the extra male nucleus among previous observers. It has also probably been figured as the functional male nucleus.

The position of the ventral canal nucleus in Taxodium at some protected place on the side of the archegonium has preserved it from destruction during the entrance of the sperm cell, and as the fusing male and female nuclei approach the base of the archegonium the ventral canal nucleus begins to extend into the center, and by amitotic division it usually gives rise to the several nuclei of different sizes which occupy the upper half of the egg (figs. IO7,II2). If the egg is not fertilized, the ventral canal nucleus generally remains unchanged in its original position ( $f$ g. 107 ), but it not infrequently increases in size and moves 
nearer the center of the egg at about the time that those of the fertilized archegonia are dividing amitotically. In these cases it does not divide, but increasing greatly in size comes to resemble the egg nucleus just as in the case described by Chamberlain ('98) (fig. II4). Indications of amitotic division may be sometimes seen in the ventral canal nucleus in unfertilized archegonia (fig. II3), but such cases are rare. The development of the ventral canal nucleus in fertilized archegonia is not the exception, but the rule. In almost all cases in which there is a proembryo present there are to be found in the upper part of the archegonium a varying number of nuclei of different sizes which have been derived from the ventral canal nucleus (figs. 1 I5, 116). In some cases, as would naturally follow when the ventral canal cell is cut off far down the archegonium, the nuclei derived from it may occupy a position near the base, and consequently near the proembryo. Fig. $I I 8$ is such a case. Here, the ventral canal nuclei are sharply distinguished from the nuclei of the embryo (only one of which is shown) by the entire absence of the starch sheath characteristic of the latter. The ventral canal nuclei are usually separated from the proembryo by a distinct area of disorganizing protoplasm, but they themselves seem to retain a part of the protoplasm at the tip of the archegonium which is not disorganized until much later ( $f g .116)$.

\section{DEVELOPMENT OF THE FEMALE NUCLEUS.}

The female nucleus in its very young stages is shown in figs. 88 and 89 . It develops more rapidly than the ventral canal nucleus and goes through the peculiar changes of structure which have already been described in more or less detail by others. The chromosomes spin themselves out into a reticulum which is apparently often arranged in a spiral form ( fig. 89). A nucleolus begins to appear early. At the stage of fig. 89 the nucleus is not yet furnished with a distinct membrane, but in fig. go the wall has appeared. There is first seen at this stage a finely granular substance which has been called metaplasmic substance by Strasburger and some recent workers. From the subsequent behavior of this substance, it would be better described 
as kinoplasm than as metaplasm, but as the former word is overworked I shall follow Chamberlain ('99) and speak of it as linin, from which it does not seem to differ. It is at first entirely distinct from the reticulum, and is only very slightly stained in Flemming's triple. The nucleolus increases in size and the linin granules become more abundant as the nucleus develops. The reticulum still remains perfectly distinct from the granular substance and stains a bright red in safranin. The nucleolus is of quite a different character from the nucleolus of the central cell previously described. It becomes larger and larger until, at the time of fertilization, it is very conspicuous ( $\mathrm{fg}$. IOO). When deeply stained, it seems to be entirely homogeneous, but on washing out a fine alveolar structure is to be seen. This does not in the least recall the irregular compound nucleolus of the central cell, and from the entirely different behavior of these two nucleoli during cell division it is evident they are of a different nature. The large nucleolus of the egg nucleus may be called the plastin nucleolus, while that of the central cell is a chromatin nucleolus. The plastin nucleolus of the egg nucleus seems to loose its stain more easily at one time than at another, as it is frequently found almost colorless. This loss of staining quality may be due to fluctuations in the amount of plastin material inclosed in its honey-comb-like structure during the active stages of development. This seems more probable, as it is often found when unstained in a collapsed condition, a distinct but thin shell being always present.

At the time of fertilization the female nucleus may vary considerably in its structure. Sometimes the linin material remains finely granular up to the time of fertilization. In such cases it is easily distinguishable from the chromatin reticulum, which on account of the huge size of the nucleus is now relatively scarce. The large plastin nucleolus is always present and is not connected in any way with the reticulum. This is another character which distinguishes it from the chromatin nucleoli already described. It is more frequently the case that the linin substance of the nucleolus, before the entrance of the male nucleus; has become grouped into an abundant reticulum, upon which granules of 
various sizes are deposited ( $f g$. IOI). The larger of these linin granules take the red stain, and thus become indistinguishable from the chromatin masses of the nucleus. At no stage in the development of the egg nucleus is it without a distinct reticulum. Whether the chromatin reticulum contracts to form separate chromatin masses or whether it remains as the coarser part of the reticulum shown in figs. IOO and $I O I$ seems uncertain.

Chamberlain ('99) and Blackman ('98) have minutely described the development of the female nucleus in Pinus Laricio and Pinus sylvestris, respectively. The former describes the complete disappearance of the nuclear reticulum at two stages of the development of the nucleus. At the time of fertilization the chromatin is all grouped in the center of the egg nucleus, the remainder being occupied by the finely granular linin substance. This condition would not be so different from the case in Taxodium if the chromatin reticulum of the latter should resolve itself into chromatin nucleoli before the organization of the linin substance into a distinct reticulum. Such a condition, however, has not been found. In the mature egg nucleus the number of small nucleoli which take the red stain with safranin is sometimes no larger than could be supplied by the chromatin of the nucleus, but when the linin substance becomes collected into large granules, which is not at all unusual, they also take the red stain and cannot easily be distinguished from the chromatin nucleoli. Their color, however, is usually a more purplish red than is the case with the chromatin nucleoli, and if the washing is continued they are the first to lose the reddish stain.

FERTILIZATION.

We left the pollen tube after describing the formation of the male cells. The divisions of the central cell of the archegonium and of the central cell of the pollen tube occur simultaneously, or almost so, in every case observed, and in this respect again resemble the Cupresseae (Strasburger,'79). Fertilization occurs in a very short time after the completion of these divisions. As stated in my previous note, both sperm cells may enter one archegonium, but this is by no means always the case, in fact 
not generally so; and when it does occur it may be considered as a failure to secure the results aimed at. When several pollen tubes have reached the archegonial group (as many as five have been noticed) the entrance of two or more sperm cells into an archegonium is not unusual, but when the number of tubes is only one or two it less often occurs. Pollen tubes sometimes are so abundant that all cannot pass into the depression above the archegonial group. Some then remain in different positions around the tip of the prothallium, and are often to be seen unchanged after their more fortunate neighbors have fertilized the archegonia. The central cell of such pollen tubes often divides at the same time with those over the archegonia, but in some cases where they are small and badly nourished the central cell does not divide at all.

In addition to the one or two sperm nuclei that enter the archegonium the disorganized remains of the stalk and tube nucleus with their surrounding protoplasm are also swept in, along with what is left of the neck cells. Prothallial nuclei are also sometimes thrown in, and quite a collection of such heterogeneous material may often be seen in the archegonial tip above the protoplasm of the egg. Most observers who have described the discharge of extra sperm nuclei or vegetative cells into the fertilized archegonium have made no distinction between entrance into archegonium and entrance into egg. Webber ('97) says that several spermatozoids may enter a single archegonium in Zamia, but that only the one that is used in fertilization actually enters the cytoplasm of the egg, the others remaining above and free in the cavity of the archegonial tip. Ikeno ('OI) calls attention to this point, and finds that in Ginkgo the supernumerary spermatozoids do not enter the cytoplasm of the egg, but remain distinct from it, even if actually pressed into its surface. He also mentions the possibility that certain nuclei in the tip of the archegonia, that have in previous cases been described as derived from the sperm cell, are probably the results of amitotic division of a persistent ventral canal cell. These observations of Webber and of Ikeno I can positively confirm in Taxodium. The supernumerary sperm cells remain separate from the cytoplasm of the 
egg, and may be long distinguished as they slowly disorganize (figs. IO4, IIO).

The functional sperm cell in its course to the egg nucleus is shown in figs. $I O O$ and $I O I$. Its protoplasm becomes intimately connected with that of the egg, but its identity is not lost at any stage. The starch sheath still remains in close contact with the sperm nucleus, and as its boundary touches the wall of the female nucleus it spreads around it more and more, while the sperm nucleus in its center finally comes in contact with the nucleus of the egg ( fig. IO2). This starch sheath of the sperm nucleus furnishes the sheath which is characteristic of the fusion nucleus.

Strasburger has several times spoken of the sudden appearance of starch in the fertilized egg of the Cupresseae. In his Neue Untersuchungen ( I 884 ) he expresses surprise at this, because, as he says, the pollen tube here contains very little starch before fertilization. His description in Juniperus of the starch sheath appearing around the fusion nucleus immediately after its formation and the subsequent behavior of the two may be applied almost word for word to Taxodium. It seems probable, therefore, that starch may yet be found in the male cells of the Cupresseae.

The sperm nucleus before contact with the female has the same character as was noticed in the pollen tube. It is difficult to distinguish it from the protoplasm around it, but a central nucleolus and a scarce reticulum may be made out in the dense substance that completely fills the nucleus. When the sperm cell enters the egg its nucleus is not more than a fifth the diameter of the egg nucleus ( $f i g$. IOO), but during its course to the latter the sperm nucleus enlarges somewhat ( $f i g . I O I$ ), and just after contact the diameter of the two nuclei is about as one to two. The male protoplasm, with its inclosed starch, now completely infolds the egg nucleus until it becomes evenly distributed around it (figs. IO2, IO3, IO5). The structure of the sperm nucleus begins to change immediately on contact with the egg nucleus. The linin substance becomes arranged into a reticulum staining deep blue with gentian, while the nucleolus seems to break up into a number of smaller granules which lie more or 
less grouped, but frequently scattered in no definite position. They were not found to be definitely located near the point of contact between the two nuclei as described by Blackman ('98) and Chamberlain ('99). The fusion nucleus begins to move to the base of the archegonium, and its male and female elements can be easily distinguished until the base is nearly reached ( fig. 106). This passing of the fusion nucleus to the base of the archegonium before division occurs has been described by Strasburger ('79, '84) in Juniperus and by Jäger ('oo) in Taxus.

The partition between the two nuclei does not entirely disappear until immediately before the first division. Fig. IIO represents the two nuclei just after the disappearance of the separating wall. The parts derived from each are still distinct, the denser part being the male. The reticulum of the sperm nucleus is arranged in a more or less radiating way, and that of the egg is also becoming thus arranged. The large plastin nucleolus of the egg nucleus may be found in all stages of fusion. In addition to the reticulum and plastin nucleolus there are also present numbers of chromatin nucleoli in each half of the nucleus. The spindle of the first division is derived entirely from the reticulum of the fusion nucleus.

The structure of the male or sperm cell of Taxodium and its behavior during fertilization are worthy of especial emphasis. The presence of large quantities of starch around its nucleus and the transfer of this starch, together with its protoplasm, to form a distinct layer around the egg nucleus, which later becomes separated from the protoplasm of the egg in the base of the archegonium to form the greater part of the young embryo, are peculiarities not as yet described in any other organism, and they seem of sufficient interest to receive attention in any comparative study of sexual cells.

All observers who have studied fertilization in the gymnosperms seem agreed that the male nucleus slips from its protoplasmic sheath as it approaches the egg nucleus and leaves it behind near the point of entrance. If the case is as they think, Taxodium is an exception here.

In his well-known work on chromatophores, leucoplasts, etc., 
A. F. W. Schimper demonstrates the presence of plastids in the egg cells of plants. Taking the occurrence of starch as an indication of the presence of leucoplasts, we find that most of the plastids of the proembryo of Taxodium are furnished by the male cell. Occasionally a few scattered starch grains may be seen in the archegonium before fertilization, but as a rule the egg protoplasm is entirely free from them at maturity. Chromatophores or leucoplasts might of course be present in the egg without the occurrence of starch, and as such bodies are rather difficult to demonstrate without special methods, their presence cannot be denied. Blackman's ('98) observation of leucoplasts in the male cell of Pinus has already been referred to.

\section{THE EMBRYO.}

Fig. I 20 shows an early stage in the formation of the spindle of the first division. The reticulum has become less coarse, the larger granules seeming to become transformed into smaller ones which characterize the fibers of the spindle at this stage. The outlines of the fusion nucleus are still quite distinct, and its fibers pass into those of the spindle imperceptibly. The chromatin has become arranged on the more homogeneous fibers in the center, and form ill-defined, much-elongated bodies which are not yet grouped into a definite plate. It will be seen that the spindle is multipolar at its origin. Stages of older spindles were not found.

The plastin nucleolus derived from the egg nucleus does not disappear during the spindle formation or during division of the nucleus. It is generally inclosed in one of the daughter nuclei, but is sometimes left free in the surrounding cytoplasm. The two daughter nuclei of the first division are first separated a considerable distance ( $f i g$. I $2 I$ ), but later approach nearer and are surrounded by the same starch sheath (fig. II 7 ). Their structure is very similar to that of the egg nucleus before fertilization, a plastin nucleus, a chromatin reticulum, and a large amount of finely granular linin material being present. As the fusion nucleus approaches the base of the archegonium, it may rotate so that the part derived from the sperm nucleus lies nearest the base of the archegonium (fig. I06). The large vacuole of the 
egg becomes broken up into smaller ones as the fusion nucleus approaches it, and in some cases almost disappears; often, however, the distinct starch-containing protoplasmic sheath of the fusion nucleus or its daughter nuclei is surrounded on both sides by large vacuoles ( fig. II 7 ).

The two daughter nuclei of the first division very soon prepare for the second division. Fig. I22 shows such a nucleus in an early stage of mitosis. The chromatin is arranged in distinct rods, the linin granules have formed the reticulum, and the large plastin nucleolus is conspicuous. Fig. I23 represents a late anaphase in the spindle of the second division. The number of chromosomes is evidently greater than in the division of the central cell. At this time the distinctive protoplasm of the proembryo has filled the base of the archegonium and is becoming more and more distinct from the ordinary egg cytoplasm above it. During this division and the one following, the plastin nucleolus is frequently left outside of the daughter nuclei, and may be broken up into several parts which lie free in the cytoplasm. Fig. I 24 gives the usual arrangement of the first four nuclei of the proembryo. They lie tetrad-fashion in the base of the archegonium, and a narrow zone of disorganizing protoplasm is beginning to appear above the starch-containing sheath around them. The cytoplasm is arranged in radiating lines from the nuclei. In fig. I 26 the third division has taken place. Several plastin nucleoli are present in the cytoplasm. In fig. 125 the four nuclei of the second division are arranged in an unusual manner. They lie in one plane at the base of the archegonium and are bounded above by a large vacuole.

Spindles of the third division do not have any definite arrangement in reference to each other or to the axis of the archegonium, but their position seems to depend a good deal upon the width of the archegonium. After the formation of the daughter nuclei, however, these become arranged as fig. II 6 . Two are situated side by side at the base, and six lie above them in one plane. While this is the usual arrangement, it is not uncommon to find only one at the base, while the other seven are arranged above it. In a few cases there were three below 
and five above. An abnormal condition is shown in fig. I28. Here two of the eight nuclei produced by the third division have not joined in the formation of the basal group, but remain some distance above, quite separate from the proembryo beneath. Two nuclei are at the base in this case, as usual, but the number above is only four, thus making up the total eight. All these nuclei are in division. The section is somewhat oblique, so that the base of one of the upper cells is shown above the two basal cells.

After the cells are arranged as mentioned, they become separated from each other by delicate cell walls, the upper tier remaining open at the top. The fourth division now takes place almost simultaneously in all of the nuclei. The axes of the spindles in the upper tier are parallel with the axis of the archegonium (fig. 127). There is thus cut off from the upper cells an equal number of nuclei which lie free in the cytoplasm of the egg and form the rosette (fig. I29). Cell walls are produced by this division and the middle tier is now completely closed (fig. 129). By referring to fig. I27 it will be seen that the starch is all grouped in the base ends of the upper tier of open cells, and that the lower poles of the spindles are imbedded in it. When walls are formed all the starch is inclosed in the middle tier with the exception of a few scattered grains in the tip cells. The spindles in the lower cells lie at right angles to the ones above, and form a tier of four cells, or of six in those cases where three original cells have been arranged at the tip, or only two where there is but one tip cell. The middle tier now elongates into the suspensors ( $f i g .133$ ), the nuclei and most of the cytoplasm appearing at the lower end. Further division in the tip cells does not occur until the suspensors have greatly elongated.

The formation of the embryo proper shows much variation. The suspensors from a single archegonium only rarely remain completely united at their tips, but usually separate more or less. The supernumerary suspensors are left behind at various positions, so that at the time of the first division of the tip cells the number of suspensors and tip cells is usually the 
same. Each tip cell divides independently of the others, even when they are near together, and different stages of development are found in embryos from the same archegonium. Generally the tip cells are separated by the spreading or unequal growth of the suspensors. Fig. I 43 shows two embryos from the same archegonium, each with its own suspensor. In fig. I44 the embryo and suspensor shown are situated at a considerable distance from any others.

Figs. $140-142$ are serial sections through a group of embryos from one archegonium. There are four in the group, only three of which are shown. It will be seen that the growth in each proceeds independently, and some of them are more advanced than others. In fig. I39 a two-celled and a three-celled embryo are represented. The first wall is almost always inclined and produces two cells generally of unequal size. The second wall arises in the distal larger cell, and is nearly at right angles to the first. The following divisions cannot be systematized by any rule, but, as will appear from the figures, are irregularly disposed. Fig. 135 shows a suspensor bearing two embryos on its tip. It was teased from a prothallium and mounted whole. Fig. 136 is a more magnified view of its tip; the two embryos are proceeding each on its own course in spite of the close contact of their original walls. In fig. 146 the more advanced embryo seems to be formed of three distinct parts which may be interpreted as derived from three separate tip cells which proceeded alone in their development for a time, but being closely associated have united to form a single embryo. In fig. 145 a single suspensor bears a single embryo. The embryonal tubes have appeared, but are not quite so much developed as in fig. 146 . In $f g .147$ is shown the most advanced stage obtained of the young embryo. The embryonal tubes are very numerous and extend about four times farther up than is shown in the figure. They have completely filled the space previously occupied by the suspensor, of which no trace can be seen at this time. Three abnormal embryos are shown in figs. $130-132$.

From this description it will be seen that the development of the embryo of Taxodium differs from all other conifers. In 
Taxus (Jäger, '99) and Cephalotaxus (Arnoldi, 'oo) there are more than eight free nuclei present before cell formation, and the tiers are not so definite as in Taxodium. In the Cupresseae (Strasburger, '72) the tiers are at first composed of single cells, while in the Abieteae only one tier is first formed which then gives rise to four by successive divisions. Coulter ('97) and Coulter and Chamberlain ('or) have described peculiarities in the number of embryos formed from one archegonium, and in the relation of suspensors to embryos in Pinus Laricio, which are not unlike the diversities found in Taxodium.

\section{SYSTEMATIC POSITION OF TAXODIUM.}

The family Taxodieae as arranged by Eichler is acknowledged a tentative one, and when we compare the gametophytes of Sequoia and Taxodium, the only two genera of this family in which this part of the life history has been followed, we are impressed, not with similarities, but with divergencies; and it becomes at once apparent that, if gametophytic characters are of any consequence in classification, the group as it now stands is an artificial one and must be rearranged. The points of divergence between Taxodium and Sequoia are so striking that to retain them longer in the same group would do violence to taxonomic principles. In the large number of functional megaspores and prothallia present in its sporangia Sequoia is markedly primitive, and in the arrangement and number of its archegonia it is, so far as known, sui generis. Its male gametophyte is imperfectly known, the young stages being quite unstudied.

In the preceding pages attention has been called in passing to certain of the more evident structural similarities between Taxodium and the Cupresseae, and for the sake of brevity they will not again be rehearsed here. It is sufficient to say that Taxodium agrees with the Cupresseae in all gametophytic characters that seem to me of much taxonomic importance, and I think it evident that such essential agreement with the Cupresseae on the one hand and such fundamental divergence from Sequoia on the other must necessitate the removal of Taxodium from its connection with the latter and its insertion in the former family. 
Such a change will require us to discard the name Taxodieae and combine the remaining genera of the family into some tentative group of another name until further study shall make their position clear.

\section{SUMMARY.}

The staminate cones begin to develop in September or October, and by winter the pollen mother-cells are formed. In spring starch is removed from the cells of the sporophyll and stored in the mother-cells, where it remains through their divisions and disappears in the pollen grain as the exine is being formed. The exposed wall of the microsporophyll is but two layers thick.

The reducing divisions in the pollen mother-cells resemble those in the Larix and the reduced number of chromosomes is probably twelve. There is a fairly well developed resting stage after the first division in the mother-cells.

About ten days after the reducing division a division of the pollen grain occurs which separates at once the generative cell from the tube cell. No sterile prothallial cells are formed.

From two to three weeks after pollination, when the pollen tube has grown some distance, the generative cell divides into the central cell and stalk cell, and these move down toward the tube nucleus. The pollen tube reaches the prothallium earlier than in any case previously described, sometimes even before the formation of a cellular tissue in the latter.

The arrangement of the nuclei in the pollen tube is the same as in other conifers.

The central cell has a distinct Hautschicht of its own and resembles in outline that of Taxus and the Cupresseae. It divides simultaneously with the division in the central cell of the archegonium, and the two sperm cells thus formed move apart slightly. They are furnished with a dense layer of starch around the nucleus, a peripheral finely granular layer often containing globules of plastic material, and a Hautschicht. Its nucleus is densely filled with granular material and has a coarse chromatin recticulum and a nucleolus.

The ovulate cones also begin their development in early fall and continue growing slowly, as the weather permits, through 
the winter. At the time of pollination the single megaspore mother-cell may be distinguished. It is filled with starch, as are also the tapetal cells around it. Two reducing divisions occur, but only three cells are formed, the upper of the two first produced not dividing again. The lower of the two potential megaspores resulting from the second division in the lower cell develops into the female gametophyte, the two upper cells disorganizing.

As the spore develops in sprouting, the tapetal cells around it grow and divide, and disorganizing the nucellar cells around them pass the nourishment to the prothallium within. How long this tapetum persists is not certain, but it probably lasts until the prothallium is mature.

The archegonia are arranged as in the Cupresseae. The number of the neck cells vary from two to sixteen or more. The central cell is very long and contains two conspicuous kinoplasmic areas, one at the upper end near the nucleus and the other in the lower end beneath the large central vacuole. When the ventral canal nucleus is cut off the upper of these masses takes part in the division, while the fragmented lower one fills the base of the archegonium with peculiar figures.

A ventral canal nucleus is cut off just before fertilization, but it is not separated from the cytoplasm of the egg and after fertilization moves back toward the center and divides amitotically. It probably assists in nourishing the embryo.

The spindle of the ventral canal cell division is almost entirely of nuclear origin, and the chromosomes are derived largely from the nucleolus. The egg nucleus contains a large amount of granular material, but a chromatin reticulum is always present. This granular material is largely used in the formation of the spindle of the fusion nucleus.

Fertilization occurs about the middle of June, and two or more sperm cells may enter an archegonium. Only one, however, becomes fused with the egg cytoplasm. As a rule one pollen tube fertilizes two archegonia.

The sperm cell with its starch, protoplasm, and nucleus passes through the cytoplasm of the tip of the egg and reach- 
ing the female nucleus enfolds it. Its starch is uniformly distributed around the fusion nucleus and passes with it to the base of the archegonia to be included in the cytoplasm segregated off as the proembryo. The larger part of the cytoplasm of the egg takes no direct part in the formation of the embryo, but is digested and used by the latter in its growth.

The first division occurs after the fusion nucleus has reached the base of the archegonium.

Eight free nuclei are formed, which arrange themselves in two tiers, the upper of which generally contains six, the lower two. Cell walls are now formed, but the upper side of the upper tier is left open. This open tier now divides by walls at right angles to the long axis of the archegonium into the rosette of free nuclei above and the suspensors below. The two cells of the lower tier divide at the same time by walls parallel to the long axis of the archegonium, and thus four cells instead of two are produced in one plane.

The suspensors as they elongate may. or may not separate, and thus one or several embryos may be formed from one archegonium.

It is thought that the family Taxodieae as now composed is an artificial one; that Taxodium itself must be removed to the Cupresseae, leaving Sequoia and perhaps other as yet imperfectly known genera of the present family Taxodieae to be included in a family of their own under another name.

\section{NOTE.}

Since the completion of this work in May, I90I, several papers have appeared bearing more or less closely on certain points here taken up. Miss Ferguson's two papers on fertilization, etc., in Pinus (Annals of Botany, I90I), and Arnoldi's Beiträge zur Morph. de Gymn. V. (Bull. Soc. Imp. Nat. Moscow, No. 4, 1900), dealing with fertilization, embryo formation, etc., in the "Sequoiaceen," are important, and would have been referred to frequently in the text had they appeared before this work was handed in. Miss Ferguson confirms Blackman's ('98) statement that the sperm cells of Pinus are furnished with a cyto- 
plasm of their own, though the outline of the cell seems to be neither so regular in shape nor so definite in outline as in other groups of gymnosperms. She finds no starch in the male cells, although much is present in the pollen tube. Miss Ferguson also suggests that the "spongy" tissue is useful in nourishing the prothallium, and brings out other interesting points, which must, however, be passed by here.

Arnoldi, in the communication mentioned, finds starch in the sperm cells of Sequoia, Cryptomeria, and Taxodium, and notes its transference to the embryo. He also considers necessary the removal of Taxodium (and several other genera) into the Cupresseae; but on certain points of fact in developmental processes our work does not agree.

In the recent Belfast meeting of the British Association Mr. Harold Wager presented a paper on the function of the nucleolus, in which he is reported as finding that "this body, in the cases examined by him, appears to be intimately connected with the nuclear network, and contains chromatin material which contributes directly to the formation of the chromosomes" (Nature $67: 20$. I902). These results are of interest in connection with my conclusions.

The University of North Carolina, Chapel Hill, N. C.

\section{LITERATURE CITED.}

Arnoldi, W., '99a': Beiträge zur Morphologie der Gymnospermen. I. Bull. Soc. Nat. Moscow I4:329-34 I. pls. 7-8. I899.

- $99^{\mathrm{b}}$ : Beiträge zur Morphologie der Gymnospermen. II. Bull. Soc. Nat. Moscow 14: 405-422. pls. 10-11. 1899.

— 'о०: Beiträge zur Morphologie der Gymnospermen. III. Flora 87 : 46-63. pls. $1-3$. I 900 .

— 'oo: Beiträge zur Morphologie der Gymmospermen. IV. Flora 87 : I94-204. pls. 6-7. I900.

Belajeff, W., '9i : Zur Lehre von dem Pollenschlauche der Gymnospermen. Ber. Deutsch. Bot. Gesell. 9:280-286. pl. 18. I89 I.

- '93: Zur Lehre von dem Pollenschlauche der Gymnospermen. Ber. Deutsch. Bot. Gesell. II : I96-201. pl. 12. I893.

Blackman, H., ' 98 : On the cytological features of fertilization and related phenomena in Pinus sylvestris. Trans. Roy. Soc. 190:395-426. pls. I2-I4. 1898 . 
Chamberlain, C. J., '98: Winter characters of certain sporangia. Bot. GaZ. $25: 125-128$. pl. II. 1898.

'99: Oogenesis in Pinus Laricio; with remarks on fertilization and embryology. Bot. Gaz. 27 :268-280. pls. 4-6. 1899.

Coulter, J. M., '97: Notes on the fertilization and embryogeny of conifers. Bот. Gaz. $23: 40-43$. pl. 6. I897.

and Chamberlain, C. J., 'or: Morphology of Spermatophytes. Part I. Gymnosperms. New York, I gor.

Davis, B. M., ' 98 : Kerntheilung in der Tetrasporen-mutterzelle bei Corallina officinalis L. var. Mediterranea. Ber. Deutsch. Bot. Gesell. 16: 266-272. pls. $16-17.1898$.

Dixon, H. H., '94: Fertilization of Pinus sylvestris. Ann. Botany $8: 21-34$. pls. 3-5. 1894 .

DugGar, B. M., '99: On the development of the pollen grain and the embryo-sac in Bignonia venusta. Bull. Torr. Bot. Club 26:89-105. pls. 352-354. I899.

Farmer, J. B., ' 92 : Occurrence of two prothallia in ovule of Pinus sylvestris. Ann. Botany $6: 213$, fig. I. 1892 .

GARDINER, W., '83: On the continuity of the protoplasm through the walls of vegetable cells. Phil. Trans. Roy. Soc. London 35 : I63-I66. I883.

Goroschankin, J., '83: Zur Kentniss der Corpuscula bei den Gymnospermen. Bot. Zeit. 41:825-831. pl. $7 \mathrm{~A}$. 1883 .

Hirasé, S., '95: Étude sur la fécondation at l' embryogénie du Ginkgo biloba. Jour. Coll. Sci. Imp. Univ. Tokio 8:307-322. pls. 3I-32. 1895 .

Hofmeister, W., '5 I : Vergleichende Untersuchungen. i 85 I.

Ikeno, S., '98: Untersuchungen über die Entwickelung der Geschlechtsorgane und der Vorgäng der Befruchtung bei Cycas revoluta. Jahrb. Wiss. Bot. 32: 557-602. pls. 8-10. 1898.

'o I : Contribution à l'étude de la fécondation chez le Ginkgo biloba. Ann. Sci. Nat. Bot. 13:305-318. pls. 2-3. I 901 .

JäGER, L., '99: Beiträge zur Kenntniss der Endospermbildung und zur Embryologie von Taxus baccatu L. Flora 86:241-288. pls. 15-19. 1899.

Juel, H. O., 'oo: Beiträge zur Kenntniss der Tetradentheilung. Jahrb. Wiss. Bot. 35 : 626-659. pls. 15-16. 1900.

Juranyi, L., '82: Beiträge zur Kenntniss der Pollen-Entwickelung der Cycadeen and Coniferen. Bot. Zeit. 40: 814-8I8, 835-844. I882.

Murrill, W. A., 'oo: The development of the archegonium and fertilization in the hemlock spruce (Tsuga canadensis). Ann. Botany 14: 583607. pls. 31-32. I 900 .

Mitzkewitsch, L., '98: Ueber die Kerntheilung bei Spirogyra. Flora 85: 8I-124. pl. 5. I 898 .

Shaw, W. R., '96: Contribution to the life history of Sequoia. Bot. Gaz. 21 : 332-339. pl. 24. I896. 
Sokolowa, Mlle. C., '9o: Naissance de l'endosperme dans le sac embryonnaire de quelques Gymnospermes. Bull. Soc. Nat. Moscow. pl. 2. I 890 .

Strasburger, E., '72: Die Coniferen und die Gnetaceen. 1872.

'77: Die Befruchtung und Zelltheilung. Jenaisch. Zeitsch. 2: 435536. pls. 27-35. 1877 .

- '79: Die Angiospermen und die Gymnospermen. I879.

'84: Neue Untersuchungen, etc., I884.

'92: Ueber das Verhalten des Pollens und die Befruchtungsvorgänge

bei den Gymnospermen. Hist. Beitr. 4: I-I 58. pls. I-3. 1892.

'oo: Ueber Reduktionstheilung, etc. Hist. Beitr. 6: I9oo.

Webber, H. J., ' $97^{a}$ : Peculiar structures occurring in the pollen tubes of Zamia. Bот. Gaz. 23: 453-459. pl. 40. 1897.

- ' $97^{\text {b }}$ : The development of the antherozoids of Zamia. Bot. Gaz. 24 : I6-22. I 897 .

' $97^{\mathrm{c}}$ : Notes on the fecundation of Zamia and the pollen tube apparatus of Ginkgo. Вот. Gaz. 24: 225-235. pl. 10. I897.

\section{EXPLANATION OF PLATES I-XI.}

The abreviations used are : $s t$, stalk cell or stalk cell nucleus; $g r$, generative cell ; $p t n$, pollen tube nucleus ; $c c$, central cell of pollen tube; sct, sclerenchymatous cells; $v c n$, ventral canal nucleus; $e n$, egg nucleus.

PLATE I.

FIG. I. Median longitudinal section through young microsporangium; primary archesporium evident as rows of cells. $\times 400$.

FIG. 2. Microsporangium in October; tapetum differentiated. $\times 300$.

FIG. 3. Spindle of first division of microspore mother cell. $\times 800$.

FIG. 4. Anaphase of same, showing four limbs to chromosomes. $\times 800$

FIGs. 5-6. Chromosomes seen from poles as they approach them; eleven in $\mathrm{fig} . \mathrm{II} . \times 800$.

FIG. 7. Spindle of second division; mother-cell walls not yet dissolved. $\times 800$.

FIG. 8. Microspore before first division; cell wall not shown. $\times 800$.

Figs. 9-I I. Successive stages in first division of microspore. $\times 800$.

FIG. 12. Pollen grain on tip of nucellus, exine split off. $\times 800$.

FIG. I3. Pollen grain beginning to germinate, exine split off and generative cell swelling out. $\times 800$.

FIG. 14. The same; young stage of germination. $\times 500$.

FIG. I 5. Tube nucleus moving down. $\times 500$.

FIG. I6. Different relative position of generative cell and pollen tube than in above. $\times 500$.

FIG. I7. Indication of branching in pollen tube. $\times 500$.

FIG. I8. Generative cell just before commencing to divide. $\times 800$. 
FIG. I 9. Generative cell immediately after division. $\times 800$.

FIG. 20. Pollen tube with three nuclei. $\times 280$.

FIG. 2I. Central and stalk cell of same tube more magnified; stalk cell protoplasm beginning to merge into that of pollen tube. $\times 800$.

FIG. 22. All three nuclei moving down, and close together. $\times 400$.

Fig. 23. Pollen tube slightly older; stalk nucleus has passed central cell and lies by tube nucleus from which it differs in its smaller size; May I5, I $900 . \times 400$.

\section{PLATE II.}

FIG. 24. More developed pollen tube; stalk and tube nuclei alike. $\times$ 235 .

FIG. 25. Tip of ovule; pollen tube has reached megaspore in which no cell walls have yet formed. $\times 26$.

FIG. 26. Tip of pollen tube that has reached the prothallium; nuclei in usual position. $\times 400$.

Fig. 27. Central cell of pollen tube shortly before division; one free nucleus shown. $\times 800$.

FIG. 28. Central cell preparing to divide; free nuclei and protoplasm of pollen tube disorganizing. $\times 400$.

FIG. 29. Spindle of division of central cell. $\times 800$.

Fig. 30. Telophase of the same. $\times 400$.

FIG. 3I. Sperm cells separated from each other. $\times 400$.

\section{PLATE III.}

FIG. 32. Megasporophyll with the axillary megasporangium rudiment just beginning to show; Oct. 3 , I $899 . \times 95$.

F1G. 33. The same; integument beginning to appear; Jan. 4, Igoo. $\times 95$.

FIG. 34. Little older megasporophyll and ovule; March I I, I9oo, Baltimore. $\times 95$.

FIG. 35. The same; ready for pollination; megaspore mother-cell not yet divided; March 3I, I 900. $\times 80$.

FIG. 36. Longitudinal section of sporangia and sporophyll ten days after pollination; placenta now beginning to appear above the ovule; April 3, I gor. $\times 36$.

FIG. 37. Sporophyll and ovule about three weeks after pollination; micropyle closed and placenta becoming prominent; April 22, 1900. $\times 36$.

FIG. 38. Megaspore mother-cell before division. $\times 800$.

FIG. 39. The same; in synapsis. $\times$ Io30.

F1G. 40. The same; spindle of first division. $\times 950$.

FIG. 4I. The same; older spindle of first division. $\times 950$.

FIG. 42. The same; wall being formed. $\times 950$.

FIG. 43. The same; spindle of second division. $\times 950$.

FIG. 44. Megaspore with the two disorganizing spores above. $\times 950$. 
PLATE IV.

FIG. 45. Megaspore before first division; distinct zone of large cells around it. $\times 400$.

FIG. 46. Two cells of the large-celled tissue in division. $\times 800$.

FIG. 47. Germinating megaspore in middle of large-celled tissue; April 29, I $900 . \times 70$.

FIG. 48. Enlarged section of the above-mentioned tissue. $\times 400$.

FIG. 49. Longitudinal section of entire ovule five weeks after pollination. $\times 36$,

FIG. 50. Ovule showing two prothallia. $\times 70$.

FIG. 5I. Longitudinal section showing nucleated cytoplasm of wall layer of megaspore, large-celled tissue, and nucellus cells. $\times 400$.

FIG. 52. Large-celled layer around somewhat older prothallium. $\times 280$.

FIG. 53. The same; after-formation of prothallial cells. $\times 280$.

FIG. 54. Young stage, ingrowing cells of prothallium. $\times 280$.

PLATE $V$.

FIG. 55. Prothallial tubes, after closure of inner ends. $\times 280$.

FIG. 56. Two-celled stage of the same. $\times 280$.

FIG. 57. Tip of young prothallium showing group of archegonium initial cells. $\times 70$.

FIG. 58. Prothallial cell becoming multinucleate. $\times 400$.

FIG. 59. The same with five nuclei. $\times 400$.

FIG. 60. Formation of neck cells in archegonia. $\times 280$.

FIG. 6r. Older archegonium; neck cell divided. $\times 280$.

FIG. 62. Still older archegonium; kinoplasmic areas beginning to appear. $\times 28$.

FIG, 63. Nucleus of central cell of archegonium at same age as above. $\times 400$.

FIG. 64. Group of archegonia showing ten in one section, two pollen tubes above; somewhat diagrammatic. $\times 70$.

FIG. 65. Cross-section of group of archegonia, showing seventeen. $\times 85$.

PLATE VI.

FIG. 66. Archegonium showing kinoplasmic masses in central cell; after entrance of plastic stuff from neck cells. $\times 280$.

FIGs. 67-69. Jacket cells in normal activity. $\times 800$.

FIG. 70. Spindle in jacket cell at time of fertilization. $\times 800$.

FIGS. 7I-74. Stages of disintegration of nuclei of jacket cells. $\times 800$.

FIG. 75. Lower part of archegonium at time of fertilization showing proteid vacuoles. $\times 800$.

FIGS. 76-82. Successive stages in division of central cell of archegonium; fig. $76 . \times 400 ;$ figs. $77-82 . \times 800$. 
Figs. 83-9o. Successive stages in division of central cell of archegonium; figs. $83-89 . \times 800 ;$ fig. $90 . \times 280$.

FIG. 9r. Group of archegonia after formation of ventral canal nuclei. $\times 36$.

FIG. 92. Two archegonia of same group slightly more magnified. $\times 70$.

Figs. 93-96. Neck cells seen from above. $\times 400$.

FIGS. 97-98. Surface view of megaspore wall showing pits; after formation of young prothallium. $\times 800$.

FIG. 99. Pits of same wall in section. $\times 800$.

\section{PLATE VIII.}

FIG. I00. Sperm cell just entering cytoplasm of archegonium tip; its nucleus barely visible in dense starch sheath around it. $\times 800$.

Fig. Ior. Sperm cell protoplasm just touching egg nucleus; sperm nucleus not yet in contact with egg nucleus. $\times 800$.

Fig. I02. Sexual nuclei in contact; sperm cell protoplasm beginning to inclose the egg nucleus. $\times 400$.

FIG. I03. Later stage of fusion. $\times 400$.

FIG. I04. Supernumerary sperm cell in tip of archegonium. $\times 400$.

FIG. I05. Later stage of fusion; starch sheath completely inclosing the not yet entirely fused nuclei. $\times 400$.

FIG. I06. Archegonium at the stage above; fusing nuclei moving down and large vacuole broken up. $\times 70$.

FIG. I07. Egg and ventral canal nucleus in tip of an archegonium that did not get fertilized. $\times 280$.

FIG. I08. Ventral canal nucleus at tip of an archegonium of same group as above which has been fertilized and has a two-celled embryo in the base. $X$ 28 o.

FIG. I09. Ventral canal nucleus in another fertilized archegonium of same group; it has grown out into the protoplasm and is beginning to divide amitotically. $\times 280$.

FigS. IIO-112. Successive stages in growth of ventral canal nucleus in fertilized archegonia ; all with young embryos in base; extra sperm cell lying in tip of archegonium in $110 . \times 400$.

\section{PLATE IX.}

Figs. II3-II4. Ventral canal cells in archegonia that missed fertilization; others in group have been fertilized. $\times 280$.

FIG. I 15. Amitotic division of ventral canal nucleus. $\times 400$.

FIG. I 6. Archegonium with 8-celled embryo at base; wells are formed between the cells, but upper cells open above; here there are seven cells in upper tier and only one below; canal nucleus at tip; disorganized layer above embryo. $\times 400$. 
FIG. I I7. Archegonium with two-celled embryo near base; ventral canal nucleus in division above, and second sperm cell free in tip. $\times 280$.

FIG. I I 8. Ventral canal nucleus divided, lying at base of archegonium in contact with two-celled embryo, only one of the nuclei of which is shown; embryo surrounded by its starch sheath. $\times 400$.

FIG. I I9. Late stage of fusion of sperm and egg nuclei. $\times 800$.

FIG. I20. Spindle of first division of fusion nucleus; large plastin nucleolus unchanged. $\times 800$.

FIG. I2I. Two daughter nuclei of fusion nucleus, immediately after division. $\times 800$.

FIG. I22. Preparation for second division. $\times 400$.

FIG. 123. Spindle of second division. $\times 800$.

\section{PLATE $X$.}

FIG. I 24. Four-celled embryo; nuclei in usual position, two above and two below arranged tetrad fashion. $\times 280$.

FIG. I 25. Embryo of same stage as above, nuclei all arranged at base in one plane. $\times 280$.

FIG. I 26. Spindles of third division; plastin nuclei in protoplasm. $\times 280$.

FIG. I 27. Eight-celled embryo, six cells above and two below; the upper are dividing, the lower preparing to divide. $\times 280$ :

FIG. I28. Abnormal embryo, cut a little obliquely; two of the nuclei have not joined in the tier formation, but have remained a little distance above, and in dividing only one is shown; the other lies beside it in another section. $\times 280$.

FIG. I 29. Sixteen-celled embryo in three tiers; six cells in rosette, six suspensor cells, and four below. $\times 280$.

Figs. I30-I32. Abnormal embryos. $\times 28$ o.

FIG. I33. Sixteen-celled embryo after suspensors have lengthened considerably. $\times 28$ o.

FIG. I34. Cross-section through a group of seven suspensors. $\times 400$.

FIG. I35. A single suspensor carrying two embryos which are developing separately. $\times 29$.

FIG. I36. Tip of above suspensor with its two embryos more magnified. $\times 400$.

FIG. I37. A two-celled and a three-celled embryo, each on its own suspensor. $\times 280$.

PLATE XI.

FIG. 138. Two four-celled embryos; there are four embryos in the group and four suspensors; three of the embryos are four-celled, and one about six-celled. $\times 280$.

FIG. I39. A three-celled and an about eight-celled embryo; four embryos in group and three suspensors. $\times 28$.

FIgS. I40-I42. Three consecutive sections through a group of four 
embryos hung by three suspensors; the fourth embryo does not appear in these sections. $\times 280$.

FIG. I43. Two embryos, each on its own suspensor; they are from the same archegonium; there are two others in the group. $\times 280$.

Fig. I44. One embryo on one suspensor, off to itself. $\times 280$.

FIG. 145. Older embryo on much enlarged tip of suspensor; embryonal tubes beginning to appear. $\times 28$ o.

FIG. I 46. Apparently three embryos of a group uniting to form a single embryo; embryonal tubes conspicuous. $\times 280$.

FIG. I 47. Older embryo; embryonal tubes extend up about four times as far as shown. $\times 28$ o. 


\section{$2 \mathrm{BHL}$ Biodiversity Heritage Library}

Coker, William Chambers. 1903. "On the Gametophytes and Embryo of Taxodium (Concluded)." Botanical gazette 36(2), 114-140.

https://doi.org/10.1086/328384.

View This Item Online: https://www.biodiversitylibrary.org/item/93155

DOI: https://doi.org/10.1086/328384

Permalink: https://www.biodiversitylibrary.org/partpdf/223141

\section{Holding Institution}

Missouri Botanical Garden, Peter H. Raven Library

\section{Sponsored by}

Missouri Botanical Garden

\section{Copyright \& Reuse}

Copyright Status: Public domain. The BHL considers that this work is no longer under copyright protection.

This document was created from content at the Biodiversity Heritage Library, the world's largest open access digital library for biodiversity literature and archives. Visit BHL at https://www.biodiversitylibrary.org. 